\title{
Three Items for the Macroeconomic Agenda
}

\author{
Axel Leijonhufvud*
}

\section{INTRODUCTION}

Where is Macroeconomics going? The subject has changed rapidly and radically over the last 25 years. New ideas or the application of new techniques to old ideas are exploited with everincreasing speed. But in the race to do so, some themes end up neglected. This essay proposes three items for the research agenda of macroeconomists.

\section{ITEM ONE: A RETURN TO THE INTERTEMPORAL COORDINATION PROBLEM}

Keynes, it may be recalled, saw the coordination of saving and investment decisions as the core problem of macroeconomic theory. In later Keynesian economics, problems of intertemporal coordination drifted so far out of focus as to be virtually forgotten. If we are ever to get unemployment theory straight, they have to be brought back onto center stage. But the old Keynesian analysis needs to be reformulated: excessive household saving is not a problem anywhere in Europe or the Americas at present; nor, for that matter, is insufficient government spending.

Macroeconomics has to regain the intertemporal coordination problem because, without it, we are left with theories of unemployment that, in pre-Keynesian fashion, look only at the labor market and its putative 'imperfections'. Specifically, we are stuck with theories that decompose unemployment into (a) NAIRU -- the 'natural' unemployment rate which evolves slowly in pace with technological and demographic developments and changes in the distribution of marketable skills, and (b) the unemployment associated with temporary deviations from NAIRU due to lags in the adjustment of wages ${ }^{1}$.

It is clear what Keynes would have had to say about these theories: if saving exceeds investment at the NAIRU (full employment) rate of real income, the 'flexible' adjustment of money wages to the excess supply of labor will not restore the economy to NAIRU. In other words, if intertemporal coordination fails, the 'flexing' of spot wages will not by itself restore full employment equilibrium.

\section{How Did We End Up With NAIRU anyway?}

Before facing the need to recast the Keynesian analysis, it may be helpful to recount how it got lost in the first place. The story starts with the Treatise on Money.

*Dipartimento di Economia, Università degli Studi di Trento, via Inama 5, 38100 Trento, Italy. E-mail: <axel@gelso.unitn.it>. Paper delivered at the Université Nice-Sophia Antipolis Conference on 'Macroeconomics: Past and Future', April 25-26, 1996. An earlier version was presented at the University of Trento Conference on 'The Future of Macroeconomics' May 1995.

1. For a trenchant, even mordant, survey of what NAIRU has accomplished for us in empirical work, see the excellent article by Rowley (1995). 
The relevant part of the Treatise is the one that deals with bear-speculation on the exchanges. Keynes postulated a situation in which the economy had to adapt to less favorable returns to investment and to traverse to a path of slower growth. The traverse required a decline in the real rate of interest. But if average market opinion had been formed by the previously ruling level of long rate, it would turn bearish as rates start to decline. The ensuing speculation against the decline of rates would bring it to a halt short of the required level. With the interest rate too high, saving out of full employment income would exceed investment; as a consequence, income would have to decline as 'active balances' were channelled into the 'idle hoards' of bears speculating on securities prices coming back down.

In the General Theory, this story underwent a change that looks more significant in retrospect than it may have seemed at the time. In the latter work, Keynes chose to fold this speculation story into his money demand function. In writing that function out, he made it:

$$
\mathrm{M}^{\mathrm{d}}=\mathrm{kY}+\mathrm{L}(\mathrm{r}), \mathrm{r}^{\prime}<0
$$

But, to accommodate the bear-speculation story of the Treatise, the Liquidity preference term should have been

$$
L\left(r^{*}-r\right), r^{* \prime}>0, r^{\prime}<0
$$

where $r^{*}$ denotes the level of interest rate to which average market opinion thinks rates will revert. Such a formulation would have made it clear that the speculative stabilization of rates might occur around any level of long rate, not just at the 'liquidity trap' floor.

In Modigliani's famous 1944 article, however, the liquidity trap became Keynes's 'special case'; the case in which unemployment was due to the failure of the interest rate to equate full employment saving with investment. Patinkin (1948) showed that a sufficiently strong Pigou-effect could reduce saving to a level consistent with full employment also in this case. In subsequent reprintings of his article, therefore, Modigliani conceded that Keynes's special case could not be claimed to demonstrate the consistency of persistent unemployment with perfectly flexible wages.

Perhaps the issue might have been more strongly contested had not the special liquidity trap case already been substituted for the more general case of 'market rate exceeding natural rate'. As the 1930's receded into history, the liquidity trap came increasingly to be seen as an irrelevancy. In any case, the conclusion that the Pigou-effect showed that 'sticky wages' were a necessary condition for unemployment became almost universally accepted. Textbooks in macroeconomics reinstated the Classical theory that Keynes had sought to replace -- under the heading, of course, of 'Keynesian economics'.

The arguments against the Pigou-effect nonsense need not be rehashed here ${ }^{2}$. But one needs to be quite clear about the position that the acceptance of the argument for it left the Keynesians in. When Phelps ${ }^{3}$ and Friedman levelled their devastating attacks against the notion of a stable Phillips curve, Keynesians were surely obliged to concede that inflation would make the short-run curve shift ${ }^{4}$. They were not obliged to accept the 'natural rate' of unemployment, at least not in the sense that soon became the accepted one, namely, that rate of unemployment to which the economy would converge as soon as money wages had had time to 'flex'. But with the acceptance of the Pigou-effect, they had abandoned all thought of intertemporal coordination problems ${ }^{5}$ and had, in effect, committed themselves exactly to the notion that cyclical unemployment was due to the 'stickiness' of money wages. To avoid sailing as dose to total 'policy ineffectiveness' as Friedman was now doing, therefore, the response left to them was that wages 'in the real world'

\footnotetext{
${ }^{2}$ See Leijonhufvud (1968, eh. 5) and Leijonhufvud (1981
} 
- as academic economists say when it occurs to them that there is one -- adjusted a good deal more slowly than Monetarists liked to think.

This was an error that was to prove fatal both to the practical influence of Keynesianism and to its ability to recruit first-rate young academic talent into an ageing school. The Quantity Theory could not explain business cycles without assuming 'sticky' wages, so Monetarists were perforce wedded to that hypothesis. The Keynesians were now bent on outflanking Friedman \& Co. on this front. The adaptive expectations schemes that were advanced as explanations of slow wage-adjustment made this brand of Keynesianism an easy target for New Classical accusations that the entire theory was based on 'irrational behavior'. To which the New Keynesians have responded by bravely proposing sundry 'more rational' reasons for sticky prices.

\section{The Real Interest Rate}

In motivating his own departure from the Classical theory of interest, Keynes (1936, pp. 190-192) pointed out that it was the full employment assumption that allowed Ricardo to maintain that the rate of profit uniquely determined the interest rate. Since he (Keynes) was developing a theory of unemployment, he could not go Ricardo's route.

Modern finance theory, intertemporal general equilibrium theory, and no longer-somodern Monetarism have taken that route -- albeit in the opposite direction. Here it is assumed that in efficient markets interest rates will coordinate intertemporal activities appropriately. Given this assumption, the proposition that wage adjustment in the labor market is all that is required to bring the system to NAIRU would be justified. Keynes's strategy was to attack the Classical conception at what is surely its weakest point: the presumption that real interest rates would coordinate saving and investment. When they did not do so, he deduced, wage flexibility will not guarantee full employment.

\section{Signal Extraction -- If You Please}

Keynes's story and the stories told by the economists of his generation do not appeal to modern tastes. Too many stock characters on stage: the consumer, the worker, the banker, the entrepreneur, the stock market speculator, and more. And who has patience with the antics that result from all the rigid idiosyncracies and informational asymmetries of this cast? It smacks of Commedia del Arte. $A$ modern audience prefers Pirandello or Beckett. So the economists of today expect to see a solitary representative agent, under the mathematical spotlight on a bare and denuded stage, asking agonizing questions of himself: 'What does it all mean?' (signal extraction) or 'I know I have optimized, but - is that all there is?' (policy ineffectiveness).

\footnotetext{
${ }^{3}$ Phelps is of course associated with Friedman in the critique of the Phillips curve. But he has also done more than anyone else in trying to bring the profession's attention lack to high real rates as the source of persistent unemployment (Fitoussi \& Phelps 1988; Phelps 1990 and 1994).

${ }^{4}$ After all, Phillips himself had pointed out in the original article (Phillips 1958) that it would not be stable under inflationary conditions.

${ }^{5}$ To this day, the intertemporal coordination assumption remains a neglected issue. In the recent 'Journal of Economic Perspectives' symposium on the natural rate of unemployment, it does not rate a mention. Cf., Stiglitz (1997), Gordon (1997), Galbraith (1997), Rogerson (1997), Staiger, Stock and Watson (1997).
} 
Parts at least of Keynes's story can be adapted for the present day stage. Let us have one lonely producer on an island of the Phelps archipelago. He has used $\mathrm{x} \%$ as his opportunity cost of capital for some time. Now he does not think that additional investment on his island will yield $\mathrm{x} \%$ any longer. His problem is: how much of this decline in the marginal efficiency of capital is specific to his island and how much of it affects the whole archipelago? If he could be sure that it was universal, he would invest anyway. But believing that high returns are still available on some island, he will hold back and go liquid. This rewrite accomplishes for Keynes's plot the same thing as did Lucas's rewrite for Friedman's. It eliminates the (perhaps) not sufficiently motivated information asymmetry between industrial managers and the stock market players. And it may give a more realistic seeming account of the increased flexibility preference which often accompanies a cyclical slowdown.

\section{Non-Keynesian Intertemporal Coordination Failures}

Bringing Keynes up to $\operatorname{code}^{6}$ does not make his theory of the 1930's relevant to the 1990's, however. A relentless passion for saving has not been a pervasive problem among the Western countries and those countries in East who have had the 'problem' do not seem to have suffered from it.

Yet, intertemporal coordination failures abound today and they affect both countries with high and with low rates of saving. Japan had its long, great run-up of the stock market and real estate markets, followed by the collapse of the Nikkei and the long drawn-out bad loans crisis of its banking system. Sweden and Finland had to rescue their banks in the wake of the collapse of major real estate bubbles. The Savings \& Loan crisis of the United States was of moderate proportions in comparison. Economic reform in Mexico first attracted large capital inflows and created a consumption boom. When doubts about the sustainability of the current account deficit began to spread in the market, the capital inflow reversed and the boom collapsed ${ }^{7}$. Drastic devaluations spared neither Sweden nor Mexico from prolonged periods of large-scale unemployment (for Sweden, the 1990's have been worse than the 1930's). The expectational contagion from the Mexican debacle caused an attack also on the Argentinian peso. Argentina's currency board regime survived but the 'Tequila effect' of the capital outflow caused a major increase in unemployment as well as banking problems nonetheless. The scenario is now being replayed by Thailand and its neighbours.

So, cases that do not appear to be just obvious instances of equilibrium real business cycle theory are not difficult to find. Some of them may be more Hayekian than Keynesian ${ }^{8}$. But in this day and age overinvestment booms seem less of a danger than overconsumption booms - such as the cases of Mexico, Argentina or, a decade ago, Brazil. The collapses of these booms reveal a prior general overestimate of wealth ${ }^{9}$. The unemployment that they produce is prolonged by allaround attempts to restore liquidity to balance sheets. The social consequences of these intertemporal coordination failures are serious. They merit our attention.

6. The reference is to Peter Howitt's discussion of 'the difficulty of making progress in a science where adherence to an increasingly complex code of formal ideas has become the overriding criterion of success, rather than the fruitful modelling of observed phenomena' (cf. Howitt 1996).

7. Cf. Heymann (1994). His theoretical analysis of precisely this kind of case appeared in 'Economia Mexicana' almost a year before the outbreak of the crisis. 


\section{ITEM TWO: PRODUCTION THEORY, THE LABOR MARKET AND INCOME DISTRIBUTION ${ }^{10}$}

We have seen a great development of axiom-based theorizing over the last 30 or 40 years, and a great reliance on it. If only one could have some faith in those axioms! In the wake of Kahneman and Tversky et al. cynical remarks about the axioms of choice theory are now admissible even in polite company. But the axioms of production theory seem even more suspect.

\section{Ricardo's Farm}

Macroeconomics is still dominated by the image of the Ricardian farm: constant returns when both land and labor can be varied; smoothly diminishing returns when labor is varied, land held constant. Increasing returns have finally come onto the theoretical agenda in the recently burgeoning literature on endogenous growth ${ }^{11}$. This work has brought to the forefront a number of empirically important ideas. But it is not radical enough - it tries too hard to 'tame' the non-convex beast it is letting loose so that it will behave itself within an otherwise unchanged framework and not wreck all the comfortable intellectual furniture of competitive general equilibrium. It does not go deeply enough into the foundations of production theory; it does not pay sufficient attention to the complementarities $^{12}$ between inputs and between intermediate products lurking behind the increasing returns postulated; as a consequence, it fails to delve into the implications for labor market behavior, unemployment and income distribution.

The macroeconomy consisting of Ricardian farms has a smoothly convex transformation surface. When the composition of demand changes, farmers need only move some acreage out of corn and into wine or vice versa. A simple gradient procedure in the direction of higher land rent will lead them to the new equilibrium; no large, discontinuous moves -- no jumps in the dark -- are required. And a farmer who finds himself making losses even with the right output mix need only cut back on his variable inputs so as to raise their marginal products until they earn their keep.

Unemployment theory in this setting looks similarly reassuring. As long as the Ricardian farmworker does not hold out for a wage exceeding his marginal product, some farmer should take him on. Finding the farm where his marginal product is highest may take a bit of trudging around the countryside. The workers passing on the highways and byways of this Cobb-Douglas landscape present a reassuring mental image of the 'natural rate' of unemployment. They do not present a social problem of great consequence; in fact, their search unemployment is performing the socially valuable arbitrage function of equating the marginal product of labor in all locations.

\section{Smith's Factory}

The Smithian pin-making factory gives us an alternative parable of production, one where continuity and convexity is not everywhere to be found (Leijonhufvud 1986). In it,

\section{'the division of labor depends upon the extent of the market'}

8. If our reference point is the General Theory. In the Treatise on Money, Keynes himself had a good deal to say about 'Credit Cycles.'

9. Cf. Heymann and Sanguinetti (forthcoming).

10. This section draws heavily on Leijonhufvud (1992).

11. Cf. esp. Romer $(1986,1987)$ and Lucas (1988).

12. Intertemporal complementarities get their due, on the other hand, in the neo-Austrian macrotheory of Amendola and Gaffard (1992). 
Increased division of labor is productive so that average factor productivity increases with the rate of output. A highly articulated division of labor, moreover, tends to be associated with a high degree of complementarity between inputs. The image to have in mind is that of an assembly line which comes to a halt if one machine breaks down or one workstation is left unmanned.

The Smithian factories form a nonlinear input-output system where each firm produces under increasing returns to scale and also uses one or more intermediate inputs produced by other increasing-returns firms. Structures of this kind can be enormously productive at high levels of activity but are, by the same token, incapable of a proportional scaling down of activities. For concreteness, picture the 'representative firm' as operating two parallel assembly lines but with some workstations in common, so that some machines and some operatives serve both lines. In recession, this firm shuts down one of the lines, cutting output in half. But the integer-constraints of the common workstations make it impossible to lay off half the workforce. Here, Okun's law is a result not of labor hoarding but of the complementarities inherent in the Smithian factory's increasing returns technology.

When output is cut back, working capital is freed and can be paid back to the bank or else given short-term placement. But subsequently, cash-flow problems become endemic in the recession. At the reduced activity level the firm's average factor productivity is lower and real unit costs consequently higher, but it cannot compensate itself by charging a higher (relative) price since its customer firms are all in the same position. Moreover, cash-flow cannot be improved by the simple expedient of cutting back on variable inputs so as to raise their marginal products ${ }^{13}$.

Real business cycle theorists have taken the pro-cyclical variation in the 'Solow residual' (i.e., the 'unexplained' change in total factor productivity) as revealing the exogenous cause driving the cycle. Fluctuations in the activity level of the system are, like seasonal movements, optimal adjustments of aggregate supply to variations in the rate of technical progress. This interpretation is probably about 180 degrees wrong. In the increasing returns economy, measured factor productivity varies procyclically whatever the cause of fluctuations. And aggregate demand remains the primary suspect.

\section{Price Cutting versus Aggregate Demand Stimulus}

The unemployed worker who has been laid off by a Smithian factory cannot induce the firm Io start up the idle assembly line by lowering the real wage at which he offers Io work. The number of jobs on the assembly line cannot be expanded by wage cutting. All the individual might achieve is Io bid the job away from someone who is still working. But a social system where even a small reduction in activity would release furious rounds of undercutting each other's wages could hardly be viable. Instead, implicit contracts dictating lay-offs by inverse seniority and strong social and economic sanctions against scabbing are likely to evolve in this setting.

The representative firm is in an analogous situation to that of its representative worker. It cannot induce an expansion of the entire input-output structure by cutting the supply price of its product. The Smithian system in its entirety depends on the 'extent of the market' to maintain the high levels of activity required to show high productivity and correspondingly high real income, which is to say, it depends on demand in the final goods sector.

13. In the recession, necessity may mother innovations that improve average factor productivity (cf., Howitt 1994). But this is not then the result of cutting back on employment along a given, continuous marginal productivity schedule. 
The component of final goods demand most likely to cause trouble is, of course, investment. In a world of Smithian technology, the intertemporal effective demand failure stressed by Keynes is not the only reason why regulation by markets of the rate of capital accumulation may falter. The scale economies internal to the firm dictate that it accumulate capital in discrete, sizeable 'lumps', rather than continuously (on a gradient approach to optimal scale). These investment decisions are particularly risky if the firm lacks information about the additions to capacity being undertaken by its competitors (Richardson 1960). In addition, the system economies external to the firm mean that the profitability of its investments depends upon the scale at which its suppliers and customers will be operating. The combination of these externalities makes it especially difficult to time investment right. Past experience, moreover, will not bestow rational expectations because economic development in the Smithian system does not repeat past patterns. It evolves through progressive differentiation of functions and through the realization of economies of scale in more and more of these functions (Young 1928).

Since the system depends on final goods demand in order to generate high per capita income and since the investment component of final goods demand can falter, old-fashioned 'Keynesian' aggregate demand management can play a useful role - if conducted by a solvent government, generally perceived as operating well within its taxing capacity. Insolvent governments can inflate but have little or no capacity to control real activity levels.

\section{Income Distribution}

If the extent of the market is not too large, the Smithian factory will earn some monopoly rent. In principle, it is a joint rent because of the complementarities among the inputs but workers had better unite because the capitalist shareholders already have. Unless labor unionizes, the capitalists tend to capture the whole rent.

As the extent of the market expands, there will be room for more firms producing at decreasing cost and competition will erode the rents. They do not disappear, of course, but end up as consumer's surpluses. In some American and European industries, labor's share of the joint rent-thatused-to-be is eroding in a new environment of worldwide competition. The process of economic development is continuously transforming such producer rents into consumer surpluses at the same time as it generates new 'niches' in which rents are to be had. The non-convexity of the productive structure of the system as a whole remains. Distribution is not governed by the Euler equation. Instead, we should recognize that a large proportion of GNP is in the nature of a joint rent. The marginal productivity theory of distribution is by and large not true and ought not, therefore, to govern our thinking on distributive issues.

\section{Technological Change}

Economic development does not repeat past patterns. If this makes investment decisions difficult for businessmen, it makes prognostication doubly difficult for the economist. The technology described above is the technology of the past, the technology of our century. The speed of technological development in the leading sectors today makes one dizzy. The poverty of imagination about what it will mean is everywhere obvious. Pundits threaten us with 500 TV channels into every home and promise that one's PC and TV will come in the same box. That is about how far our foresight extends.

The technological change of which we have seen the beginnings is likely to mean that, as a source of employment, manufacturing in the next century will go the way of agriculture in the last. Not very long ago by historical standards, we had $80-90 \%$ of the labor force in rural occupations. Now the figure is below 10 per cent and in several countries below 5 per cent. 
This will almost certainly be repeated in all the main manufacturing industries, as assembly line work is taken over by computer controlled industrial robots. It will be a wrenching social transformation for large segments of the working class and for many localities. Protection against imports will not prevent the loss of production jobs from this technological transformation. It may in fact lessen the pressure of competition from low-wage labor elsewhere, that has become such a widespread preoccupation in recent years (competition from low-tax countries may prove a worse problem). By and large, low-wage labor cannot produce to the standards of precision, uniformity, and guaranteed quality that the new technologies will deliver.

Technological change will also change the organization of work, the nature of firms, and the structure of industries. The increased versatility of computer controlled machinery should reduce the incentives for vertical integration in manufacturing and create a tendency for smaller production units. If manufacturing will be less dominated by the old type of vertically integrated giants, their place may be taken by a reincarnated merchant capitalism of trading firms that shop the world for the best low-cost subcontractors and component manufacturers and in this way pull together and then again dissolve patterns of cooperating producing units brought together in temporary alliances for particular purposes.

\section{ITEM THREE: MONEY, CREDIT, AND THE PRICE LEVEL}

Some 40 years ago, the then dominant Keynesian doctrine held that monetary policy was largely 'ineffective', and particularly so in recessions. Policy was transmitted via the real interest rate and both the elasticity of this rate with regard to base money and the interest elasticity of expenditures were thought to be small. This ineffectiveness of monetary policy pertained to money as well as real income.

About 25 years ago, professional opinion had changed considerably under the rising influence of monetarism. Monetary policy was now seen as a powerful regulator of nominal aggregate demand. Since wages and prices were (still) thought to be 'sticky', monetary impulses also had strong effects on output and employment. The central question had become whether it was wise to exploit this leverage over real magnitudes. Keynesians in general were in favor of so doing. Monetarists, impressed with the long and variable lags in the transmission process, were opposed.

Some 10 or 15 years ago, the theory of monetary policy taught in our graduate schools had changed again. At that time, the 'effectiveness' of monetary policy in regulating nominal aggregate demand was thought to be almost instantaneous. However, since money prices were governed by rational expectations, it was no longer seen as a regulator of output and employment. Moreover, expansionary monetary policy drove nominal interest rates up rather than down.

Today, it is not so easy to characterize a dominant doctrine. Rational expectations monetarism has lost its sharp logical contours. Elements of it survive, although no one any longer asserts the clear-cut doctrine of 15 years ago. And, monetary policy understood as interest-rate policy with Bank Rate as a principal instrument has made a strong come-back. But it has done so although the older doctrines that provided a theoretical foundation for Bank Rate policy have not been re-established.

The situation today appears to be one of growing incomprehension between practitioners and academics. Policy-makers find little if any guidance in the theories that claim the attention of academic economists. And the latter hardly understand what central bankers think they are doing. 


\section{The Dominant Tradition}

For the fast forty years or more, while these dramatic shifts in views on monetary policy have taken place, one theoretical tradition has dominated in monetary economics. It is associated with the names of Patinkin, Friedman, Brunner and Meltzer, and Lucas.

There are considerable differences between these thinkers but the models that we associate with these famous names have a number of properties in common:

i) The stock of money, $M$, is determined by the supply side and is independent of factors on the demand side.

ii) $M$ is controllable by the Central Bank.

iii) The domestic price level, $P$, is proportional to $M$ in equilibrium. $M$ is neutral.

iv) By changing $M$, the Central Bank can produce corresponding changes in Py. Monetary policy is 'effective' in changing nominal income, albeit with long and variable lags'.

v) In the short run, monetary policy $m a v$ also be 'effective' in changing real output, $\mathrm{y}$, and employment but only in so far as (and as long as) $\mathrm{P}$ is sticky.

We should also note a negative proposition:

vi)The Central Bank has no control over real interest rates ${ }^{14}$, although it may create transitory liquidity effects'.

This tradition has had one persistent conceptual problem throughout, namely, to provide an unambiguous definition of the money stock which is the empirical counterpart of the ' $M$ ' of the theory.

\section{The Dissenters}

All along, of course, there have been dissenters from the dominant tradition. In the Anglo-Saxon literature, the line runs from the Radcliffe Report (and R.S. Sayers) through Kaldor (1982) to Basil Moore (1988).

The positions that we associate with these names deny the propositions of the dominant tradition:

i) The stocks of money and other liquid assets are mainly determined by demand.

ii) The quantity of money, therefore, is by and large not controllable by central banks.

iii) Money is non-neutral so monetary policy can have real effects.

iv) What is the right definition of ' $\mathrm{M}$ ' for Quantity Theory purposes is either an unanswerable question or else a question for which the correct answer keeps changing.

v) Monetary policy works through changing interest rates and credit conditions and by affecting the 'liquidity' of the private sector.

vi) Since the money stock is determined by demand, causation runs from prices to money and not the other way around. Wages, rather than the supply of money, are taken to be the exogenously given determinant of the price level.

The contest between these two views has been conducted in terms which presuppose that, since the propositions of one contradict those of the other, one has to be true and the other false. But things are more complicated than that. Each theory contains important lessons. Rather than choosing between thesis and anti-thesis we should seek a synthesis 


\section{Inside and Outside Money}

Such a synthesis will have to hinge on the distinction between inside and outside money. A reworking of the monetary aspects of macroeconomics along these lines is not to be accomplished in one-third of a paper, but it should be possible to indicate the promise - and the difficulties - of the approach albeit at the cost of considerable over-simplification.

Begin with outside money. In the main, the analysis of it will follow the dominant quantity theory tradition. Outside money will be neutral (but not superneutral). It determines the equilibrium 'nominal scale' of the system. Creation of outside money produces an excess supply to which the economy must respond by raising prices. Hot potatoes ${ }^{15}$.

Inside money is credit money. Variations of inside money relative to the stock of outside money will be part of more general expansions or contractions of credit in the economy. It responds to increases in the amount of real balances demanded as the level of activity in the systems rises or falls.

When inside and outside money change in proportion, of course, the distinction is more or less superfluous. In such cases, one can proceed as if all money was outside money. Accordingly, we focus on the ratio of inside to outside money.

In various macroeconomic processes that are of interest this ratio will vary systematically. A long-run evolutionary force is almost always at work to increase the ratio as the banking system and the public at large find new ways to economize on outside money. But here we will focus on more short run matters.

\section{$\underline{\text { 1. Inflation }}$}

In an outside money inflation, such as the high inflations analyzed in Heymann and Leijonhufvud (1995), the ratio of inside to outside money is likely lo fall even as the public's demand for real balances is drastically reduced. But we may al so have inside money inflations fuelled by cumulative expansions of bank (and all other forms of) credit. In these the ratio rises. These inside money inflations cannot be sustained indefinitely, therefore, without ending in a financial crash. Hayek's overinvestment theory of the cycle postulates an inflationary process of this sort in which a banking system, elastically tied to the gold (exchange) standard, expands the real volume of credit in the economy. In this case, money fails to be 'neutral' in the sense of 'neutrality' as it was understood before Patinkin ${ }^{16}$.

\section{The Cycle and the Phillips Curve}

The price level should not be expected to vary in proportion to the money stock over the cycle. The fact that prices and wages do not so vary should not be taken as evidence per se of 'stickiness' or of failure of the markets to 'clear'. Friedman's 'dynamic' reformulation of the

15. The appropriate ceteris paribus conditions under which the 'hot potato' analogy may be used are not always so obvious, however. Warren and Pearson expected a more or less immediate reflation of the U.S. economy when President Roosevelt in 1933 drastically increased the outside money stock by raising the dollar price of gold. But the full adjustment of the dollar price level to this event had to await the decades-long 'unlearning' of the liquidity preferences induced by the Great Crash. 
Monetarist model in terms of first differences made the expected rate of inflation the strategic variable in the macroeconomic controversies of the time (Friedman 1968 and in Gordon 1974). In so doing, he accomplished two things. First, by introducing the Fisher equation (see below) as the explanation for the cyclical behavior of the money rate of interest, he defended Monetarism against the argument that Gibson's Paradox disproved the monetary impulse hypothesis. Second, he went on the attack by predicting that the Phillips curve would prove unstable in the face of variations in the rate of inflation. The American inflation of the 1970's provided indubitable evidence that inflation expectations would shift both the nominal interest rate and the short-run Phillips curve ${ }^{17}$. The result was the great Monetarist victory in the debate.

At this point, however, we should turn the original question around and ask: Why did the Phillips relation not give evidence of instability before the 1970's?

My conjecture is that the end of Bretton Woods coincided -- indeed, in part was caused by -the first outside money inflation since World War II, whereas postwar business cycles had until then been characterized by endogenous fluctuations in inside money. On this interpretation, they were predominantly 'real' (but not necessarily equilibrium) cycles in which the banking system (including the central bank) accomodated the demand for real balances. Whenever fluctuations in the demand for real balances is accomodated in this way, the nominal money supply will obviously be seen to vary with larger amplitude than the price level. To infer from such data that prices are sticky is a mistake (Leijonhufvud 1987).

Business cycles were often referred to as alternating periods of 'high and low prices' back in the gold standard era. The usage has lapsed because it presupposes a knowable benchmark relative to which prices can be judged 'high' or 'low'. The price level has to show meanreversion to trend ${ }^{18}$. The 'old' Phillips curve (or, rather, Phillips scatter), shows the record of alternating 'high' and 'low' prices, relative to the slowly evolving trend to which monetary policy would with quite considerable consistency make the system revert. President Johnson's determination to have 'both guns and butter' in the late 1960's started the outside money inflation that was to last until Reagan and Volker.

\section{Monetary Policy and the Interest Rate}

In the older monetary literature, expansionary monetary policy would reduce interest rates and its effects would by and large be transmitted by this channel. Friedman's 'dynamic reformulation' of Monetarist quantity theory in first differences, and later Lucas's rational expectations version of it, changed the presumption. Now, expansionary monetary policy would drive nominal interest rates up, through the Fisher effect. The contradiction may be resolved by distinguishing between two cases. In the first, outside money does not change but the central bank is offering to rediscount at a more favorable real rate so as to engineer an expansion of the real volume of credit in the system. In the second, it collaborates with a deficit spending government in raising the growth rate of outside money, letting the nominal scale of the economy drift upwards. When this latter policy is understood for what it is, the nominal rate will rise above the real rate and show a positive correlation with the inflation rate.

16. Cf. Leijonhufvud (1991). The pre-Patinkin concept of 'neutrality' was a criterion for the conduct of monetary policy requiring that inside money behave -- or be made to behave -- exactly as outside money, so as not to distort relative values and resource allocation.

17. As argued in Item One above, the evidence from this period should not be taken as proof of the NAIRU hypothesis.

18. Priority for making clear how crucial is the distinction between monetary regimes that do and those that do not exhibit mean-reversion in the price level belongs to Benjamin Klein (1975). 
As is well-known, the so-called Fisher equation has not been empirically confirmed. The coefficent on the expected inflation term (variously generated) generally comes out substantially less than one. From the standpoint that I am advocating, this is understandable since not only do our two types of episodes occur in the data ${ }^{19}$ but they are also intermingled with the real business cycle processes in which real rates and prices move together. Fisher's own empirical work ${ }^{20}$ uncovered only a most tenuous link between inflation and nominal interest rates which is not surprising since he worked with gold standard data.

\section{Problems}

Making up hypotheses is easy. Confirming or disproving them is another matter.

The major Monetarists did of course consider the possibility that the money income correlation was due to the endogeneity of money. Empirically, however, they focused their attention on the relationship between the money stock and the monetary base (e.g., Brunner and Meltzer 1993). Except for some systematic but minor variations in the currency-deposit ratio, the base money multiplier shows virtually no cyclical variation. Hence, they drew the conclusion that the determinants driving the cyclical movements of the money stock lie on the supply and not on the demand side.

The monetary base and the stock of outside money are not the same. Most obviously, the monetary base includes central bank rediscounts (bank borrowed reserves) which are not part of outside money. By the theory sketched above, therefore, the part of the money stock based on borrowed reserves should be found to have a lesser impact on the price level than the part based on outside money. If that were all, the theory should be testable in a fairly straightforward way. But there are problems.

Take the Kaldorian perspective for a moment: it is agreed that the government can by deficit spending, financed by creating new outside money, inflate the economy. But its ability to do so through central bank operations is disputed. The Cantabrigian response to monetarism revives the 150 years old reflux argument of the Banking School: the Central Bank cannot cause bank liabilities to be created that exceed the amount demanded; it cannot generate that excess supply of money that will force an increase in spending, incomes and ultimately prices.

The question that arises is: Granted that central bankers cannot bake 'hot potatoes' from scratch, might not these gentlemen at least be able to heat some leftovers? Yesterday's deficits are there in the outstanding stock of bonds. If some of it is monetized through open market purchases today, are the effects going to differ from what would have occurred had the deficits been monetized simultaneously? The situation with respect to inside versus outside money should be the same in either case. Similarly, an open market purchase in recession that is reversed in boom should have the same effect as an increase in rediscounts over the same period. Sargent (1987) has laid out the logic of the case in an intertemporal model with complete markets: the proper definition of ' $\mathrm{M}$ ' for the purpose of determining the nominal scale of an economy is

19. Even a 'pure' outside money inflation may fail to satisfy the Fisher equation. This is because such inflations are likely to be random walks in the growth rate of the (outside) money stock. Such processes increase the prospective price level uncertainty at distant relative to near future dates and, therefore, induce increased flexibility preference. This reduces short term real rates. Cf. Leijonhufvud (1984).

20. Although Fisher had a monetary causation theory of the cycle, he recognized an important endogenous component to the cyclical pattern of the money stock and did not, therefore, apply his long-run 'monetarist' theory to the relationships between money, prices, and interest rates over the cycle. Cf. Laidler (1991b, pp. 78-79) and pp. 90-95). The original work on the issue is Fisher (1896). 
'outside money net of future budget surpluses'.

To which one would add 'plus future monetizations of already outstanding debt'.

Not for the first time, theory fails to handle the econometrician a clearly defined and operational concept! But at least he is not alone. Everyone living in the economy under study has faced the same inference problem. In this respect, Brunner and Meltzer surely saw the problem correctly. In defending their Monetarism against the Lucas version, they stressed the inability of agents accurately to distinguish transient from permanent additions to the money supply (this should be modified to read 'outside money supply', however).

This problem, shared by all transactors and monetary empiricists alike, can be alleviated by institutional design, that is, by constraining the behavior of the monetary authorities so as to simplify the inference problem that agents face. A prohibition against central bank financing of the government is an obvious example (and one with numerous precedents, for example, among the Central Banks newly created in the period between the World Wars). But it would take us too far afield to pursue the topic here.

\section{A PERSONAL CONCLUSION}

Where macroeconomics is going, I am sure I do not know. In the last twenty years, it has been driven by technological opportunity rather than by social problems as never before. As European countries entered a second decade of unemployment rates well into the double digits, macrotheorists kept busy elaborating models of intertemporal labor-leisure substitution. On the policy front, 'unanticipated money' was for some years deemed the best -- although unfortunately useless -- idea. Where modelling technology will take us next is no easier to predict than where galopping information technology will take the world at large. In economics, technology driven modelling shows a startling lack of theoretical continuity, if by 'theory' we mean a system of beliefs about the world around us. New Classical Economics, which started out more monetarist than Friedman or Brunner and Meltzer, in a few short years ended up as Real Business Cycle Theory -a doctrine that gives less of a role to money than any macrotheory ever before.

More than ten years ago, I made the complaint that, to someone coming from L.A., macroeconomics seemed to have taken a turn very similar to the movies: more and more simpleminded plots but ever more mind-boggling special effects. One would like to look forward to a macroeconomics whose plots will give more insight into the human condition. In particular, I hope that in the not too distant future, the up-and-coming generation of macroeconomists will turn their admirable skills to working out the three plot lines sketched above.

\section{REFERENCES}

Amendola, Mario and Jean-Luc Gaffard (1992). Intertemporal Complementarity and Money in an Economy Out of Equilibrium, Journal of Evolutionary Economics. 2: 131-145.

Blanchard, Olivier and Lawrence F. Katz (1997). What We Know and Do Not Know About the Natural Rate of Unemployment, Journal of Economic Perspectives. 11: 51-72.

Brunner, Karl and Allan H. Meltzer (1993). Money and the Economy: Issues in Monetary Analysis. Cambridge: Cambridge University Press.

Friedman, Milton (1968). The Role of Monetary Policy, American Economic Review. 58: 1-17. 
Fisher, Irving (1896). Appreciation and Interest. New York: Macmillan.

Fitoussi, Jean-Paul and Edmund S. Phelps (1988). The Slump in Europe. Oxford: Basil Blackwell.

Galbraith, James K. (1997). Time to Ditch the NAIRU, Journal of Economic Perspectives. 11: 93-108.

Gordon, Robert J. (ed.) (1974). Milton Friedman 's Monetary Framework: A Debate with his Critics. Chicago: University of Chicago Press.

Gordon, Robert J. (1997). The Time-Varying NAIRU and its Implications for Economic Policy. Journal of Economic Perspectives. 11: 11-32.

Heymann, Daniel (1994). Sobre la Interpretation de la Cuenta Corriente, Economia Mexicana. 3: 31 -59.

Heymann, Daniel and Axel Leijonhufvud (1995). High Inflation. Oxford: Oxford University Press.

Heymann, Daniel and Pablo Sanguinetti (forthcoming). Business Cycles from Misperceived Trends. Howitt, Peter (1994). Adjusting to Technological Change. Canadian Journal of 'Economics. 27: 763-775.

Howitt, Peter (1996). Cash in Advance, Microfoundations in Retreat, in: Daniel Vaz and Kumaraswamy Velupillai (eds.), Inflation. Information and Institutions. London: Macmillan.

Kaldor, Nicholas (1982). The Scourge of Monetarism. New York: Oxford University Press.

Keynes, J. Maynard (1930). A Treatise on Money. London: Macmillan.

Keynes, J. Maynard (1936). The General Theory of Employment, Interest and Money. London: Macmillan.

Klein, Benjamin (1975). Our New Monetary Standard: The Measurement and Effects of Price Uncertainty, 18801973, Economic Inquiry. 13: 461-484.

Laidler, David (1991 a). The Austrians and the Stockholm School: Two Failures in the Development of Macroeconomics, in: Lars Jonung (ed.), The Stockholm School of Economics Revisited. Cambridge: Cambridge University Press.

Laidler, David (19916). The Golden Age of the Quantity Theory. Princeton: Princeton University Press.

Leijonhufvud, Axel (1968). On Keynesian Economics and the Economics of Keynes: A Study in Monetary Theory. New York: Oxford University Press.

Leijonhufvud, Axel (1981). The Wicksell Connection, in: Axel Leijonhufvud, Information and Coordination: Essays in Macroeconomics. New York: Oxford University Press.

Leijonhufvud, Axel (1984). Inflation and Economic Performance, in: Barry N. Siegel (ed.), Money in Crisis. Cambridge, Mass.: Ballinger Publ. Co.

Leijonhufvud, Axel (1986). Capitalism and the Factory System, in: Richard Langlois (ed.), Economics as Process: Essays in the New Institutionalist Economics. New York: Cambridge University Press.

Leijonhufvud, Axel (1987). Rational Expectations and Monetary Institutions, in: Marcello de Cecco and Jean-Paul Fitoussi (eds.), Monetary Theory and Economic Institutions. London: Macmillan.

Leijonhufvud, Axel (1989). Information Costs and the Division of Labour, International Social Science Journal. 120: $165-176$.

Leijonhufvud, Axel (1991). Comment on David Laidler, in: Lars Jonung (ed.), The Stockholm School of Economics Revisited. Cambridge: Cambridge University Press.

Leijonhufvud, Axel (1992). Keynesian Economics: Past Confusions, Future Prospects, in: Alessandro Vercelli and Nicola Dimitri (eds.), Macroeconomics: A Survey of Research Strategies. Oxford: Oxford University Press. 
Lucas, Robert E. (1988). On the Mechanics of Economic Development, Journal of Monetary Economics. 22: 342.

Modigliani, Franco (1944). Liquidity Preference and the Theory of Interest and Money, Econometrica, XII, as reprinted in: Friedrich A. Lutz and Lloyd W. Mints (eds.) (1951), Readings in Monetary Theory. Philadelphia: 186-239.

Moore, Basil J. (1988). Horizontalists and Verticalists: The Macroeconomics of Credit Money. Cambridge: Cambridge University Press.

Patinkin, Don (1948). Price Flexibility and Full Employment, American Economic Review, XXXVIII, reprinted with revisions in: F.A. Lutz and L.W. Mints (eds.) (1951), Readings in Monetarv Theory. Philadelphia: $252-283$.

Phelps, Edmund S. (1990). Seven Schools of Macroeconomic Thought. Oxford: Oxford University Press.

Phelps, Edmund S. (1994). Structural Slumps: The Modern Equilibrium Theory of Unemployment, Interest, and Assets. Cambridge, Mass.: Harvard University Press.

Phillips, A. W. (1958). The Relation Between Unemployment and the Rate of Change of Money Wage Rates in the United Kingdom, 1862-1957, Economica. 25: 283-299.

Rogerson, Richard (1997). Theory Ahead of Language in the Economics of Unemployment, Journal of Economie Perspectives. 11: 73-92.

Romer, Paul M. (1986). Increasing Returns and Long-Run Growth, Journal of Political Economy. 94:1002-1037.

Romer, Paul M. (1987). Growth Based on Increasing Returns Due to Specialization, American Economic Review. 77: 56-62.

Rowley, Robin (1995). History, Structure and the Wandering Natural Rate of Unemployment," Economique Appliquée, 48:1: 135-157.

Staiger, Douglas, James H. Stock and Mark W. Watson (1997). The NAIRU, Unemployment and Monetary Policy, Journal of Economic Perspectives. 11: 33-49.

Stiglitz, Joseph (1997). Reflections on the Natural Rate Hypothesis, Journal of Economic Perspectives. 1 I : 3-10.

\section{SUMMARY}

The paper consists of three brief essays in persuasion. The first argues for renewed attention to the problems of intertemporal coordination that were once at the core of all saving-investment theories of business fluctuations. Neglect of these problems confuses unemployment theory, since the natural rate hypothesis implicitly assumes intertemporal equilibrium. The second suggests that a production theory emphasizing increasing returns and complementarities is more helpful than Cobb-Douglas in understanding labor market behavior and certain income distribution issues. The third stresses the need to distinguish between exogenous outside money impulses and endogenous inside money variations in explaining the relationship between money, output, and the price level over time.

\section{ZUSAMMENFASSUNG}

Der Artikel besteht aus drei kurzen Uberzeugungsessays. Der erste tritt dafür ein, Problemen der intertemporalen Koordination erneut Aufmerksamkeit $\mathrm{zu}$ widmen, die einst im Zentrum aller Theorien standen, die Konjunkturschwankungen durch Sparen bzw. Investitionen erklaren. Die Vernachlässigung dieser Probleme bringt Verwirrung in die Beschäftigungstheorie, da die Hypothese der natürlichen Arbeitslosigkeit implizit ein intertemporales Gleichgewicht annimmt. Der zweite Essay deutet darauf hin, dass eine Produktionsfunktion, die zunehmende Skalenerträge und Komplementaritäten betont, hilfreicher ist als die Cobb-Douglas-Produktionsfunktion, um das Verhalten der Arbeitsmärkte und bestimmte Probleme der Einkommensverteilung zu verstehen. Der dritte Essay betont die Notwendigkeit, zwischen exogenen Geldmengenimpulsen und endogenen Geldmengenvariationen zu unterscheiden, um den Zusammenhang zwischen Geld, Ausbringungsmenge und Preisniveau im Zeitablauf zu verstehen. 


\section{RÉSUMÉ}

Ce papier consiste en trois brefs essais de persuasion. Le premier plaide en faveur d'un intérêt renouvellé pour les problèmes de coordination intertemporelle, problèmes qui furent jadis au centre de toute théorie des cycles conjoneturels basée sur l'épargne et l'investissement. La négligeance de ces problèmes seme la confusion dans la théorie du chomage, car l'hypothèse du taux naturel assume implicitement l'équilibre intertemporel. Le deuxième essai suggère qu'une théorie de la production mettant l'accent sur les rendements croissants et les complémentarités est plus utile pour la compréhension du fonctionnement du marché du travail et de certains points relatifs à la distribution du revenu que l'approche traditionnelle de Cobb-Douglas. Le troisième essai souligne la nécessité de distinguer, dans l'explication de la relation temporelle entre la masse monétairc, le PIB et le niveau des prix, entre des impulsions exogènes de la monnaie dite 'outside' et des variations endogènes de la monnaie dite 'incide'. 